\title{
Low density lipoproteins added to an extender frozen or lyophilized are evenly efficient in cryoprotecting ovine sperm cells than when $16 \%$ whole egg yolk was added
}

\section{Lipoproteínas de baixa densidade em meio diluidor congelado ou liofilizado exerce o mesmo efeito crioprotetor aos espermatozoides ovinos que meio contendo $16 \%$ de gema de ovo}

\author{
Ana Maria Loaiza-Echeverri1; Betina Carla $\mathrm{Cruz}^{2}$; \\ Paola Pereira das Neves Snoeck ${ }^{3}$; Luís Cláudio Oliveira Mora ${ }^{4}$; Beatriz Parzewski \\ $\mathrm{Neves}^{2}$; Mariana Machado Neves ${ }^{5}$; Luiz Guilherme Dias Heneine ${ }^{6}$; Marc Henry ${ }^{7 *}$
}

\begin{abstract}
The aim of this study was to test different concentrations of low density lipoprotein (LDL) in replacement of whole egg yolk in extenders preserved in the aqueous or lyophilized form, for ram sperm cryopreservation using two freezing curves $\left(-40^{\circ} \mathrm{C} / \mathrm{min}\right.$ from 5 to $-140^{\circ} \mathrm{C}$ and nitrogen vapor). One ejaculate from six Santa Inês rams was collected. Each ejaculate was divided into nine different diluents as follows: Tris-16\% yolk (control), and Tris with 2, 4, 6 and $8 \%$ fresh LDL, and criopreserved in the aqueous or lyophilized form. The samples were diluted to a final concentration of $100 \times 10^{6}$ sperm $/ \mathrm{mL}$ and filled into $0.25 \mathrm{ml}$ straws. After thaw, sperm cells were evaluated for motility and sperm kinetics (CASA), and submitted to the hypoosmotic swelling test and the evaluation of the structural integrity of sperm membranes using fluorescent dyes (CFDA: PI), as well as sperm morphology and longevity. The experimental design was randomized blocks, and results were submitted to ANOVA and the averages were compared using the Scott-Knott test. There were no differences in progressive motility and functional and structural integrity of the membrane evaluated when different concentrations of aqueous or lyophilized low density lipoproteins or egg yolk were added to the extender $(\mathrm{P}>0.05)$. As for the velocity of sperm movement, the control medium had some kinetic scores similar to the extender containing LDL, both aqueous and lyophilized $(\mathrm{P}>0.05)$. Results were similar between cooling curves. Therefore, we conclude that the media containing all concentrations of LDL, aqueous or lyophilized, were able to protect the ram sperm cells during the cryopreservation process, as whole egg yolk did.
\end{abstract}

Key words: Sperm cryopreservation, low-density lipoproteins, ovine

\footnotetext{
1 Pesquisadora, Escola de Veterinária da Universidade Federal de Minas Gerais, UFMG, Belo Horizonte, MG,, Brasil. E-mail: anamvz@hotmail.com

2 Discentes, UFMG, Belo Horizonte, MG, Brasil. E-mail: betina_vet@msn.com; biaparzewski@gmail.com

3 Prof ${ }^{a}$, Departamento de Ciências Agrárias e Ambientais, Universidade Estadual de Santa Cruz, UESC, Ilhéus, BA, Brasil. E-mail: paolasnoeck@gmail.com

4 Discente, Pós-graduação Ciência Animal, UESC, Ilhéus, BA, Brasil. E-mail: 1c_@hotmail.com

5 Prof ${ }^{\mathrm{a}}$, Dept ${ }^{\mathrm{O}}$ de Biologia Geral, Universidade Federal de Viçosa, UFV, Viçosa, MG, Brasil. E-mail: mmachadoneves@yahoo. com.br

${ }^{6}$ Pesquisador, Laboratório de Imunologia, Fundação Ezequiel Dias, FUNED, Belo Horizonte, MG, Brasil. E-mail: heneinel@, gmail.com

7 Prof., UFMG, Belo Horizonte, MG, Brasil. E-mail: henrym2601@gmail.com

* Author for correspondence
} 


\section{Resumo}

O objetivo deste trabalho foi testar para criopreservação de sêmen ovino diferentes concentrações de lipoproteína de baixa densidade (LBD) em substituição à gema de ovo em meios diluidores, armazenados na forma aquosa e liofilizada, utilizando-se duas curvas de congelação $\left(-40^{\circ} \mathrm{C} / \mathrm{min}\right.$ de 5 à $-140^{\circ} \mathrm{C}$ ou vapor de nitrogênio). Os ejaculados de seis carneiros da raça Santa Inês foram fracionados e distribuídos em nove tratamentos, sendo o primeiro o meio controle (Tris-gema $16 \%$ ) e os demais meios Tris contendo lipoproteínas de baixa densidade nas concentrações de 2, 4, 6 e $8 \%$ (v/v), criopreservados tanto na forma aquosa quanto liofilizada. As amostras foram diluídas para a concentração final de $100 \times 10^{6}$ espermatozoides $/ \mathrm{mL}$ e envasadas em palhetas de $0,25 \mathrm{~mL}$. Após a descongelação foram avaliadas a motilidade e cinética espermática (CASA), morfologia e longevidade espermáticas, além da integridade funcional (HOST) e estrutural (CFDA/IP) das membranas. O delineamento experimental foi blocos ao acaso e os resultados foram submetidos a ANOVA, sendo as médias comparadas pelo teste de Scott-Knott. Quanto aos parâmetros de motilidade progressiva e integridade funcional e estrutural da membrana, todos os tratamentos testados foram similares $(\mathrm{P}>0,05)$. Quanto às velocidades do movimento espermático, o meio controle obteve alguns valores similares aos meios contendo LBD, tanto na forma aquosa quanto liofilizada $(\mathrm{P}>0,05)$. Não houve diferenças entre curvas de congelação. Dessa forma, é possível concluir que os meios contendo todas as concentrações de LBD, aquosa ou liofilizada, foram igualmente capazes de proteger as células espermáticas de ovinos, durante o processo de criopreservação, tanto quanto o meio contendo gema de ovo total.

Palavras-chave: Criopreservação de sêmen, lipoproteínas de baixa densidade, ovinos

\section{Introduction}

Artificial insemination with fresh or cooled semen is the most commonly used reproductive technique in ovines; however, has the disadvantage of reduced storage time of semen and hinders the wide dissemination of genetic material from superior animals (RABASSA et al., 2007). In ovines, the fertility rate after cervical insemination with frozen semen is generally low (8-30\%) (AISEN, 2008). These results are due to the cryopreservation sensitivity of the ovine spermatic cell, and the complex and particular anatomy of the cervix of female sheep that complicates intrauterine sperm deposition (HOLT, 2000a; CRUZ JÚNIOR, 2006).

Therefore, many researchers have aimed to improve sperm cryopreservation. Recently, several studies have shown that replacing the egg yolk in extenders with low-density lipoproteins (LDL) enhanced motility, membrane integrity, and the fertilization ability of frozen sperm from various species compared to the use of commercial extenders containing total egg yolk (MOUSSA et al., 2002; AMIRAT et al., 2004; JIANG et al., 2007; BENCHARIF et al., 2008; VARELA JÚNIOR et al.,
2009; MOUSTACAS et al., 2011; VERA-MUNOZ et al., 2009; HU et al., 2010; SILVA et al., 2014; NEVES; HENEINE; HENRY, 2014).

It has been suggested that the phospholipids present in LDL protect sperm by forming a film at the interface between the fatty acids and water, leading to the physical stabilization of the membrane. It has also been stated that LDL adheres to the sperm membrane causing influx of phospholipids and cholesterol into the membrane (FOULKES, 1977; GRAHAM; FOOT, 1987; ANTON et al., 2003). In addition, it has been shown that LDL inhibit sperm membrane destabilization by binding to bovine seminal plasma proteins (BSP); this destabilization enhances spermatic capacitation and reduces the efflux of cholesterol and phospholipids, which damages the cells when subjected to cryopreservation (MANJUNATH et al., 2002; BERGERON et al., 2004).

The addition of LDL to ovine sperm freezing extenders at concentrations ranging from 5 to $20 \%$ has been tested, and a concentration of $8 \%$ had the same cryoprotective capacity as higher concentrations (ALVAREZ et al., 2008, TONIETO, 
2008; MOUSTACAS et al., 2011). Additionally, it has been shown that when LDL were lyophilized and, then, resuspended to compose the diluting extender, this resulted on a substantial reduction in their cryoprotective capacity (MOUSTACAS et al., 2011).

Considering the cryoprotective potential of LDL together with the results from a previous study that showed that a concentration of $8 \%$ (w/v) was as effective as higher concentrations, the present study aimed to test the use of fresh LDL at concentrations lower than $8 \%$. Additionally, a different lyophilization protocol was tested as an alternative production and conservation method of extenders for ovine sperm freezing.

\section{Material and Methods}

Six rams (Santa Ines breed) aged 2- to 5-yearsold, and with a body condition score ranging from 2.5 to 3.5 (scale 1-5) were used. Prior to semen freezing, all rams were subjected to a thorough examination following the suggestions from the Manual of Andrology of the Brazilian College of Animal Reproduction (CBRA, 1998). Semen was collected using an artificial vagina and only ejaculates with at least $70 \%$ motility, a maximum of $30 \%$ spermatic abnormalities, and a minimum concentration of $1.8 \times 10^{9}$ sperm per ejaculate were used.

Sperm motility parameters were assessed in fresh and post-thawed samples was performed by using computer-assisted sperm analysis (CASA - Sperm Class Analyzer - SCA ${ }^{\circledR}$ v.4.0). The following parameters were measured: progressive motility (PM), average path velocity (VAP), progressive linear velocity (VSL), curvilinear velocity (VCL), amplitude of lateral head displacement (ALH), tail beat frequency (TBF), straightness (STR), and linearity (LIN). All measurements were carried out following manufacturer's instructions for ovine sperm analysis. The speed based on curvilinear velocity (VCL) was considered slow, average, and fast at $10-45,45-75$, and $>75$ microns/s, respectively. During straightness (STR) measurement, values $>80 \%$ were labeled as progressive. During linearity (LN) measurement, values $<50 \%$ were labeled as circular. To calculate path velocity (PV) and connectivity, 5 and 12 points were considered, respectively. Parameters were measured in 25 images taken at a rate of 25 frames per second with a head area of 3-70 microns.

Sperm concentration was determined immediately after semen collection with the aid of a Neubauer chamber. Both fresh and thawed semen samples were morphologically evaluated using the wet preparation procedure and phase contrast microscopy (Olympus). A total of 200 cells were counted and the results were expressed as a percentage value. Morphological defects were grouped in three categories: head, middle piece, and main piece defects. Sperm motility was evaluated for both samples, fresh semen post-dilution and thawed semen. This evaluation was carried out on a $100 \mu \mathrm{L}$ aliquot of each sample, which was incubated in a water bath at $37{ }^{\circ} \mathrm{C}$ and evaluated by computer analysis every $60 \mathrm{~min}$, for a maximum of $3 \mathrm{~h}$.

The functional integrity of cell membranes was evaluated using the hypoosmotic test (JEYENDRAN et al., 1984) by adding $10 \mu \mathrm{L}$ of diluted semen to $1000 \mu \mathrm{L}$ of $150 \mathrm{mOsmol} / \mathrm{L}$ fructose citrate solution. This mixture was incubated at $37^{\circ} \mathrm{C}$ for $30 \mathrm{~min}$ and thereafter fixed with $50 \mu \mathrm{L}$ of phosphate buffered formol-saline solution for later reading. A total of 200 cells per sample were analyzed using a phase contrast microscope under 400x magnification. The percentage of cells reactive to HOST c was calculated as follows: HOST c $(\%)=(\%$ changes in the tail region after the HOST c test $)-(\%$ changes in the tail region before the HOST c test) (MELO; HENRY, 1999).

The structural integrity of the plasma membrane was assessed in fresh and thawed sperm samples by the fluorescence technique using carboxyfluorescein diacetate (CFDA) and propidium iodide (PI) as 
fluorochromes as described by Harrison and Vickers (1990). Two hundred cells were evaluated using an epifluorescence microscope (Olympus) under 400x magnification using filters of 480 to $610 \mathrm{~nm}$. Sperm cells were considered structurally intact when they were completely stained with CFDA, and damaged when they were completely stained with PI or when the acrosome was stained with CFDA and the nucleus with PI.

Pure egg yolk from fresh chicken eggs was used for LDL purification. The purification was performed according to the protocol described by Moussa et al. (2002), and with the modifications proposed by Neves, Heneine and Henry (2014) and Silva et al. (2014). Fresh egg yolk or purified fresh lipoproteins were used for extender preparation. Part of the extenders containing LDL were prepared without using glycerol and freeze-dried according to the lyophilization protocol described by Neves et al. (2014). This method did not require the use of an organic solvent for LDL resuspension. All extenders contained Tris-glucose as reported by Salamon and Visser (1972). Extenders lyophilized or not, were stored for a maximum of 1 week at $-20{ }^{\circ} \mathrm{C}$ prior to their use. The control extender consisted of the basic medium containing $16 \%$ egg yolk while in the other extenders the egg yolk was replaced by LDL, which were added immediately after extraction at concentrations of $2,4,6$, and $8 \%(\mathrm{v} / \mathrm{v})$. Lyophilized extenders were reconstituted on the day of use after which $5 \%$ of glycerol was added. The osmolarity of all extenders was evaluated prior to their use. The control extender, and extenders with 2, 4, 6, and $8 \%$ aqueous LDL showed an osmolarity of 1279 , 951, 1068, 1051, and $1039 \mathrm{mOsm}$, respectively. The extenders with 2, 4, 6, and 8\% lyophilized LDL showed an osmolarity of 917 ; $932 ; 913$; and 1,027 mOsm, respectively. The $\mathrm{pH}$ of the extenders containing LDL and egg yolk was calculated in previous experiments in our laboratory and, ranged from 6.04 to 7.03 and from 6.33 to 7.64 , respectively. The $\mathrm{pH}$ of the extenders was not assessed in the present study.
Each ejaculate was split into 9 fractions and each fraction was diluted in an extender to achieve a final concentration of $100 \times 10^{6} \mathrm{sperm} / \mathrm{mL}$. These procedures were carried out at room temperature. The diluted ejaculates were loaded into $0.25 \mathrm{ml}$ straws, cooled to $5{ }^{\circ} \mathrm{C}$, and maintained at this temperature for $2 \mathrm{~h}$ before freezing. The ejaculates were frozen using 2 different methods with the aid of a freezing machine (TK 4000 model ${ }^{\circledR}$, TK Freezing Technology Ltda.). In the first method (hereafter called computerized method), a cooling rate of $-0.25^{\circ} \mathrm{C} / \mathrm{min}$ was used until a temperature of $5{ }^{\circ} \mathrm{C}$ was reached; after this, a freezing rate of -40 ${ }^{\circ} \mathrm{C} /$ min until a temperature of $-140{ }^{\circ} \mathrm{C}$ was reached. In the second method, the cooling was carried out using the freezing machine but after the equilibrium period, samples were frozen using nitrogen vapor ( $3 \mathrm{~cm}$ above the liquid column) for $15 \mathrm{~min}$. After freezing, the straws were stored in a cryogenic container for 1 week. Thawing was performed by immersing the straws in a water bath at $37^{\circ} \mathrm{C}$ for $30 \mathrm{~s}$.

The experimental design used completely randomized blocks and each animal was considered a block (SAMPAIO, 1998). The results were subjected to analysis of variance (ANOVA) and the means compared using the Scott-Knott test. Differences were considered statistically significant if $\mathrm{P}<0.05$.

\section{Results}

The values of the sperm quality parameters of the fresh semen from the 6 rams are presented in Table 1.

Table 2 shows the sperm kinetic results of the samples frozen using the 2 different methods. The samples were immediately analyzed after thawing. Sperm kinetics did not differ between freezing methods within each treatment. There was no difference between the tested concentrations of LDL and the control extender for BCF, LIN, and STR. 
The minimum and maximum values for BCF, LIN, and STR parameters ranged from $10.2 \pm 1.9$ to 11.8 $\pm 2.2 \mathrm{~Hz}, 52.7 \pm 9.6$ to $62.7 \pm 5.2 \%$, and $79.8 \pm 3.6$ to $85.2 \pm 2.5 \%$, respectively, for sperm frozen under the computerized freezing method; and from $9.0 \pm$ 0.7 to $11.7 \pm 1.2 \mathrm{~Hz}, 57.4 \pm 3.2$ to $63.1 \pm 9.1 \%$, and $79.8 \pm 5.8$ to $84.7 \pm 5.9 \%$, respectively, for sperm frozen using nitrogen vapor.

Table 1. Sperm characteristics of fresh ejaculates from six Santa Ines breed rams.

\begin{tabular}{lrc}
\hline Characteristic & Mean \pm SD & Amplitude Variation \\
\hline Volume (mL) & $1.45 \pm 0.42$ & $0.7-2.0$ \\
Total Motility (\%)* & $94.82 \pm 3.57$ & $89.44-98.39$ \\
Progressive motility (\%)* & $72.35 \pm 8.93$ & $57.76-80.20$ \\
Vigor (1-5) & $4.00 \pm 0.00$ & 4 \\
Mass Motility (1-5) & $4.67 \pm 0.52$ & $4-5$ \\
Concentration (x 10 $\mathrm{sptz} / \mathrm{mL})$ & $4.57 \pm 1.68$ & $2.98-7.74$ \\
\hline Morphology & & $72-90$ \\
Normal (\%) & $83.33 \pm 9.16$ & $0-2$ \\
Head Defects (\%) & $0.50 \pm 0.84$ & $0-4$ \\
Middle Piece Defects MP (\%) & $1.67 \pm 1.86$ & $9-28$ \\
Main Piece Defects MPD (\%) & $14.50 \pm 8.46$ & \\
\hline
\end{tabular}

Samples collected $=6$ (six), one ejaculated by animal; $\mathrm{SD}=$ standard deviation; $\mathrm{sptz}=$ spermatozoa; $\mathrm{MP}=$ Middle Piece; $\mathrm{MPD}=$ Main Piece. *Sperm motility was assessed using computer-assisted sperm analysis (CASA - SCA $®$ ).

Source: Elaboration of the authors.

In the computerized method, lower VAP $(\mu \mathrm{m} / \mathrm{s})$, $\operatorname{VSL}(\mu \mathrm{m} / \mathrm{s})$, and VCL $(\mu \mathrm{m} / \mathrm{s})$ values were observed in extenders with total egg yolk and $6 \%$ aqueous LDL; total egg yolk and $8 \%$ lyophilized LDL; total egg yolk, respectively, than in the other extenders tested. Regarding ALH $(\mu \mathrm{m})$, lower values of this parameter were observed in the computerized method in extenders with total egg yolk; 2, 4, 6, 8\% aqueous LDL; and $8 \%$ lyophilized LDL than in the other extenders tested. In the nitrogen vapor freezing method, extenders with total egg yolk, 4 and $6 \%$ aqueous LDL, and 4\% lyophilized LDL showed lower TM (\%) and PM (\%) values compared with the other extenders tested. In this method, lower $\operatorname{VAP}(\mu \mathrm{m} / \mathrm{s})$ and VCL $(\mu \mathrm{m} / \mathrm{s})$ values were also observed in all extenders except in those with $8 \%$ lyophilized LDL. Finally, all extenders except those with $6 \%$ aqueous and $2 \%$ lyophilized LDL showed lower ALH $(\mu \mathrm{m})$ values.

Over the 180-min incubation period, a gradual and significant decrease in the mean postthaw progressive motility was recorded. In the computerized freezing method, the only significant difference in progressive motility was observed at $60 \mathrm{~min}$, when higher values were recorded $(\mathrm{P}>$ 0.05 ) in samples containing $8 \%$ lyophilized LDL extender. A similar result was observed at 120 and $180 \mathrm{~min}$, when the nitrogen vapor method was used. The lowest motility values were observed during incubation when the control extender was used in both freezing methods $(\mathrm{P}>0.05)$. 


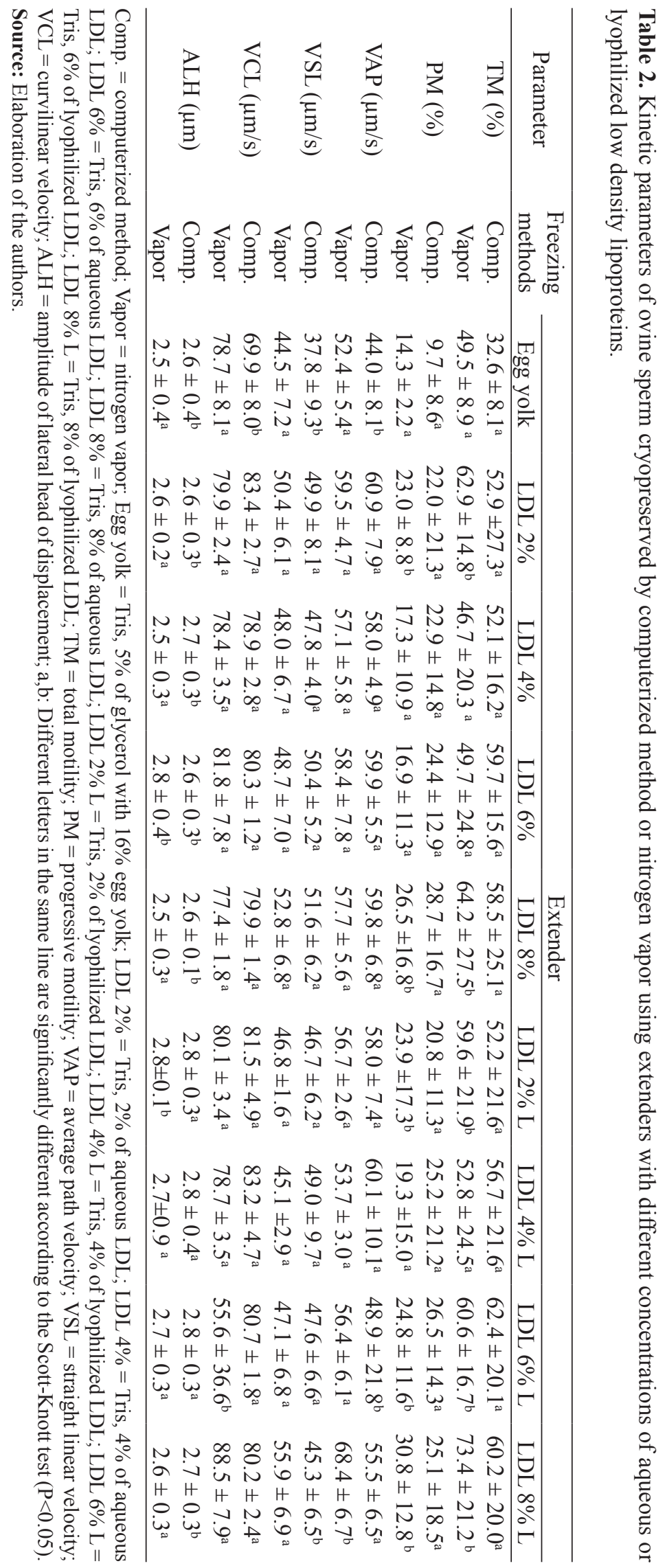


Results of the structural and functional integrity of sperm membranes assessed by combining both fluorochromes, propidium iodide (PI) and carboxyfluorescein diacetate (CFDA), and the hypoosmotic test are shown in Table 3. After thawing, the percentage of cells with fully intact membrane did not differ between extenders $(\mathrm{P}$ $>0.05)$ in both freezing methods. The average percentage of intact cells in sperm frozen using the computerized method was $12.7 \pm 3.3 \%$ a value 81.6 $\pm 4.7 \%$ lower than in fresh semen. An average of $14.8 \pm 2.8 \%$ cells reacted to the hypoosmotic test in the thawed semen. Thus, after cryopreservation an average reduction of $68.1 \pm 6.9 \%$ was recorded in the percentage of reactive cells. The percentage of cells reacting to the hypoosmotic test did not differ between extenders $(\mathrm{P}>0.05)$ in the both freezing methods.

Table 3. Structural and functional integrity of ovine spermatozoa plasma membrane cryopreserved in extenders with different concentration of low density lipoproteins submitted to different freezing methods

\begin{tabular}{lcccc}
\hline & \multicolumn{2}{c}{ Computerized Method } & \multicolumn{2}{c}{ Nitrogen Vapor } \\
\hline \multirow{2}{*}{ Extender } & $\begin{array}{c}\text { Intact (\%) } \\
(\text { CFDA }+)\end{array}$ & $\begin{array}{c}\text { Cells Reactive to } \\
\text { HOST (\%) }\end{array}$ & $\begin{array}{c}\text { Intact (\%) } \\
(\text { CFDA }+)\end{array}$ & $\begin{array}{c}\text { Cells Reactive } \\
\text { to HOST (\%) }\end{array}$ \\
\hline Egg yolk & $18.0 \pm 5.4$ & $16.0 \pm 10.5$ & $18.3 \pm 10.8$ & $13.2 \pm 3.3$ \\
LDL 2\% & $11.2 \pm 5.9$ & $14.8 \pm 4.0$ & $13.2 \pm 6.7$ & $17.4 \pm 3.2$ \\
LDL 4\% & $11.5 \pm 8.5$ & $10.8 \pm 4.4$ & $7.2 \pm 5.5$ & $14.5 \pm 5.1$ \\
LDL 6\% & $10.7 \pm 5.3$ & $12.7 \pm 5.3$ & $9.2 \pm 8.1$ & $13.6 \pm 7.4$ \\
LDL 8\% & $8.2 \pm 3.3$ & $17.8 \pm 8.1$ & $14.4 \pm 11.5$ & $18.4 \pm 8.5$ \\
LDL 2\% L & $15.0 \pm 7.2$ & $14.5 \pm 3.0$ & $11.2 \pm 11.3$ & $19.0 \pm 8.7$ \\
LDL 4\% L & $16.3 \pm 11.6$ & $18.3 \pm 10.6$ & $11.3 \pm 10.3$ & $13.0 \pm 9.6$ \\
LDL 6\% L & $9.6 \pm 9.2$ & $17.3 \pm 9.4$ & $14.2 \pm 6.5$ & $16.8 \pm 10.4$ \\
LDL 8\% L & $13.7 \pm 8.3$ & $11.2 \pm 6.3$ & $14.2 \pm 10.6$ & $18.3 \pm 11.6$ \\
\hline
\end{tabular}

Egg yolk $=$ Tris, $5 \%$ of glycerol with $16 \%$ egg yolk; LDL $2 \%=$ Tris, $2 \%$ of aqueous LDL; LDL $4 \%=$ Tris, $4 \%$ of aqueous LDL; LDL $6 \%=$ Tris, $6 \%$ of aqueous LDL; LDL $8 \%=$ Tris, $8 \%$ of aqueous LDL; LDL $2 \%$ L = Tris, $2 \%$ of lyophilized LDL; LDL $4 \%$ L $=$ Tris, $4 \%$ of lyophilized LDL; LDL $6 \%$ L = Tris, $6 \%$ of lyophilized LDL; LDL $8 \%$ L = Tris, $8 \%$ of lyophilized LDL. There were no differences among the extenders for any freezing method evaluated according to the Scott-Knott test $(\mathrm{P}<0.05)$.

Source: Elaboration of the authors.

The morphology assessment using phase contrast microscopy revealed no difference between extenders $(\mathrm{P}>0.05)$. After thawing, the mean number of cells with normal morphology and head defects was $94.5 \pm 1.0 \%$ and $0.5 \pm 0.3 \%$, respectively.

\section{Discussion}

The results indicate that egg yolk replacement by LDL was not able to fully prevent the damage to sperm cells during the freezing or thawing processes. In all quality parameters except sperm morphology, a substantial decrease in quality between pre- and post-thaw period was observed. However, extenders containing LDL in both aqueous and lyophilized form at concentrations of $2 \%$ to $8 \%$ provided a similar or superior cryoprotective capacity as that by extenders containing $16 \%$ egg yolk. Moustacas et al. (2011) demonstrated that LDL at concentrations of $8-20 \%$ had the same cryoprotective capacity as the whole egg yolk from ovine sperm, indicating that the use of concentrations above $8 \%$ is not required. In the present study, we demonstrated that total egg yolk used in freezing extenders can be replaced by LDL at very low concentrations, such as $2 \%(\mathrm{v} / \mathrm{v})$, during ovine spermatozoa cryopreservation. This concentration is smaller 
than those reported in previous studies (ALVAREZ et al., 2008; TONIETO, 2008; HU et al., 2010; MOUSTACAS et al., 2011). Furthermore, Silva et al. (2014) reported that LDL concentrations below $4 \%$ are not ideal for preserving ovine sperm during freezing. However, the study on swine sperm cells by Bianchi et al. (2011) reported no difference in post-thaw motility or sperm membrane integrity when LDL at $2 \%$ concentration were used during cooling and freezing. The effectiveness of LDL in sperm cell cryoprotection has also been reported in other species (PACE; GRAHAM, 1974; FOULKES, 1977; WATSON, 1981; MOUSSA et al., 2002; MANJUNATH et al., 2002; BERGERON et al., 2004; BERGERON; MANJUNATH, 2006; NEVES; HENEINE; HENRY, 2014).

Sperm may suffer less damage during cryopreservation processes with species-specific freezing and thawing temperature curves (LIMA, 2010). Similarly, a less damaging temperature decline rate can be obtained depending on the composition of the diluting extender (LIMA, 2010). In an attempt to record the effect of the temperature decline rate in post-thaw sperm viability, two freezing methods (freezing machine and nitrogen vapor) were used in this experiment. A similar trend in qualitative loss was observed in the spermatozoa cryopreserved using the two systems. It is possible that different freezing temperatures may reduce spermatozoa damage when used in combination with the concentrations of lipoproteins tested here. In conclusion, different cooling rates can be used when LDL are added to ovine semen extenders.

Total motility results described in this study were similar to those found in the literature regarding cryopreserved ovine semen (MAIA, 2006; TILBURG et al., 2008; GOULARTE, 2009), although different extenders were used. Additionally, the motility reduction observed when compared with that of fresh semen in Tris extender containing different concentrations of fresh LDL was similar to that recorded by Maia (2006) and Moustacas et al.
(2011), who found a 63.5 and $62.1 \%$ reduction in motility, respectively, after cryopreservation.

In both freezing methods, progressive motility was found to be lower than expected considering the total sperm motility obtained in all extenders. Subjective observations of progressive motility made without the aid of the computerized system (CASA) in other experiments in our laboratory, often provided higher values than those recorded by CASA. This difference may be related to the accuracy level of the parameters incorporated in the CASA software to define progressive motility.

Evaluation of the sperm kinetic parameters after each cooling/freezing method showed that thawed sperm cells did not show similar results in all extenders. When the computerized method was used, there was no difference in total and progressive motility between the different diluting extenders used. However, extenders with egg yolk, 4\% and $6 \%$ aqueous LDL, and 4\% lyophilized LDL had lower values of total and progressive motility when nitrogen vapor was used. The VAP, VSL, VCL, and ALH values varied significantly among the different diluting extenders within each cooling/freezing method; however, fluctuations of these kinetic attributes did not follow an up- or downward trend in relation to LDL concentration nor in relation to the preservation method. The lack of a variation pattern, added to the fact that no differences were found in sperm membrane integrity nor in response to the hypoosmotic test between extenders in each tested freezing method, does not provide a strong enough cause/effect relation to formulate a hypothesis that could explain these results. Differences between ejaculates from the same and different individuals in the ability to withstand freezing (SALAMON; MAXWELL, 2000; HOLT, 2000b; MAIA, 2006) could cause these specific fluctuations.

Several studies have evaluated the relationship between sperm kinetics and fertility characteristics. For example, Didion (2008) found no significant correlation between motility parameters obtained by CASA assessed individually and birth rate 
in pigs. The authors explained that the lack of correlation may have been caused by the high number of sperm in the insemination dose used $\left(3-5 \times 10^{9}\right)$, the number of inseminations per estrus (2-3), or due to the low number of females inseminated per male (20). In their study on pig sperm, Broekhuijse et al. (2012) demonstrated that progressive motility, VCL, and BCF are related to the frequency of deliveries; and that the total motility, VAP, VSL, and ALH affected slightly but significantly $(\mathrm{P}<0.05)$ the number of piglets born. In sheep, the kinetic variables VAP, VCL, and VSL have been associated with the increased ability of sperm to reach the fertilization site and fertilize the egg (CORANDIN et al., 2013). However, since no well-defined cause and effect trend was observed between the composition of the diluting extenders and between the preservation methods with the kinetic attributes in this experiment, we cannot infer whether diluting extenders with LDL would result in a higher or lower fertilization probability.

Nevertheless, the values of various sperm kinetics attributes were often smaller when using an egg yolk-based diluting extender instead of most other extenders. This effect might be similar to that found by Strzeżek, Koziorowska-Gilun and Stawiszyńska (2012) who demonstrated that canine sperm cryopreservation impaired the functionality of the antioxidant enzymes, superoxide dismutase (SOD) and glutathione peroxidase (GPx). Furthermore, the reduction in the activity of these two enzymes was higher using an egg yolk-based diluting extender than in extenders with LDL. Corandin et al. (2013) showed that diluting extenders with LDL instead of whole egg yolk reduced the negative effects caused by the cooling and freezing processes on the activity of the antioxidant enzymes from ram spermatozoa.

According to $\mathrm{Hu}$ et al. (2010), the use of LDL in concentrations up to $8 \%$ in diluting extenders for the cooling and freezing of ovine semen produced better results in motility, motion characteristics, mitochondrial activity, membrane integrity, and DNA than extenders with $20 \%$ of egg yolk. Taken together, these results demonstrate that LDL can protect the structure and functionality of sperm cells during the cryopreservation process similarly or, in particular moments, better than egg yolk.

A large individual variation in the sperm ability to resist freezing processes has been reported, even within the same breed and species (SALAMON; MAXWELL, 2000; HOLT, 2000a; MAIA, 2006). If we consider the high standard deviation detected in some of the parameters evaluated here, it is possible that the variation observed in the present study could mask a possible effect of the LDL concentration and/or of the cooling curve. It was noted that the sperm from 2 of the 6 animals showed much greater motility than the other animals in all extenders (reaching in some diluting extenders with lipoproteins post-thaw progressive motility values $50 \%$ higher than the rest). Among the animals that had lower results, one of them showed a significant improvement in sperm motility with a diluting extender with $2 \%$ aqueous LDL, while in others, the extenders that best cryoprotected the sperm cells were those with concentrations of 6 or $8 \%$. However, in this study, individual variation was not analyzed.

No substantial differences were observed in the evaluated sperm parameters when the diluting extender with LDL were preserved in aqueous form or subjected to lyophilization. The lyophilization process used in the present study was performed using the complete diluting extender with LDL, excluding the glycerol, which was added at the time of use. Incorporation of lyophilized LDL allows their resuspension without difficulty. In the experiments carried out by Moustacas et al. (2011) and Neves, Heneine and Henry (2014) in rams and dogs, respectively, pure lipoproteins were previously lyophilized and, later, incorporated into extenders at the time of use. In these experiments, it was necessary to resuspend the lipoproteins in $0.1 \mathrm{M}$ phosphate buffer $\mathrm{pH} 7$ containing an organic solvent ( $1 \%$ Tween 20$)$ to reduce lump formation in the media. In the studies by Moustacas et al. (2011) 
and Neves, Heneine and Henry (2014), the use of lyophilized LDL at concentrations lower than $8 \%$ did not result in adequate cryoprotection of sperm cells. In our study, lyophilization was performed using the complete diluting extender without glycerol, which did not require any solvent; thus, the hypothesis of Moustacas et al. (2011) and Neves, Heneine and Henry (2014) about the potential damage in postthawed sperm quality due to solvent use seems consistent considering the results obtained in our study.

Marco-Jiménez et al. (2004) demonstrated that the use of lyophilized egg yolk in extenders was effective in ovine sperm cryopreservation and maintained its fertilizing capacity as demonstrated by in vitro fertilization. Therefore, the use of lyophilized diluting extenders, including those containing LDL, for spermatozoa cryopreservation can be an alternative for longer storage periods.

\section{Conclusion}

LDL extenders preserved in aqueous or in lyophilized form at concentrations of 2 to $8 \%$ can be used instead of whole egg yolk for ovine spermatozoa cryopreservation. The efficiency of the lipoproteins did not change depending on the 2 freezing methods used and lyophilization may be an alternative for the conservation of extenders containing LDL.

\section{Acknowledgments}

To the Fundação de Amparo à Pesquisa do Estado de Minas Gerais - FAPEMIG for the financial support.

\section{References}

AISEN, E. G. Processamento e conservação do material seminal. In: AISEN, E. G. Reprodução ovina e caprina. São Paulo: MedVet, 2008. p. 75-87.
ALVAREZ, M.; CASTRO, D.; MURO, J.; MARTINEZPASTOR, F.; MATA-CAMPUZANO, M.; GARCÍA, C.; ANEL, L.; PAZ, P. Effect of different LDL concentrations in the freezing extender on semen quality of frozenthawed ram spermatozoa. Biology of Reproduction, Madison, v. 78, n. 1, p. 114-259, 2008.

AMIRAT, L.; TAINTURIER, D.; JEANNEAU, L.; THORIN, C.; GÉRARD, O.; COURTENS, J. L.;ANTON, M. Bull semen in vitro fertility after cryopreservation using egg yolk LDL: a comparison with Optidyl ${ }^{\circledR}$, a commercial egg yolk extender. Theriogenology, California, v. 61, n. 5, p. 895-907, 2004.

ANTON,M.;MARTINET, V.;DALGALARRONDO, M.; BEAUMAL, V.; DAVID-BRIAND, E.; RABESONA, H. Chemical and structural characterization of lipoproteins purified from hen egg yolk. Food Chemestry, England, v. 83 , n. 2, p. 175-183, 2003.

BENCHARIF, D.; AMIRAT, L.; ANTON, M.; SCHMITT, E.; DESHERCES, S.; DELHOMME, G.; LANGLOIS, M. L.; BARRIÈRE, P.; LARRAT, M.; TAINTURIER, D. The advantages of LDL (low density lipoproteins) in the cryopreservation of canine semen. Theriogenology, California, v. 70, n. 9, p. 1478-1488, 2008.

BERGERON, A.; CRÊTE, MARIE-HÉLÈNE; BRINDLE, Y.; MANJUNATH, P. Low-Density Lipoprotein fraction from hen's egg yolk decreases the binding of the major proteins of bovine seminal plasma to sperm and prevents lipid efflux from the sperm membrane. Biology of Reproduction, Madison, v. 70, $\mathrm{n}$. 3, p. 708-717, 2004.

BERGERON, A.; MANJUNATH, P. New insights towards understanding the mechanisms of sperm protection by egg yolk and milk. Molecular Reproduction and Development, Rhode Island, v. 73, n. 10, p. 1338 1344, 2006.

BIANCHI, I.; MADEIRA, E. M.; SCHNEIDER, A.; RABASSA, V. R.; CORREAA, E. K.; LUCIA JUNIOR, T.; CORRÊA, M. N. Efeito de diferentes métodos de congelamento, diluentes e tempos de resfriamento sobre a qualidade do sêmen suíno criopreservado. Acta Scientiae Veterinariae, Porto Alegre, v. 39, n. 1, p. 949-955, 2011.

BROEKHUIJSE, M. L. W.; SOSTARIC, E.; FEITSMA, H.; GADELLA, B. M. Application of computer-assisted semen analysis to explain variations in pig fertility. Journal of Anim Science, Champaign, v. 90, n. 3, p. 779789, 2012.

COLÉGIO BRASILEIRO DE REPRODUÇÃO ANIMAL - CBRA. Manual para exame andrológico e avaliação de sêmen animal. 2. ed. Belo Horizonte: CBRA, 1998. 49 p. 
CORANDIN, E. M.; MEIRINHOS, P. G.; PRADO, T. F.; OLIVEIRA FILHO, B. D.; PEREIRA, P. H. S.; GAMBARINI, M.L. Efeito da cisteína adicionada ao meio diluente sobre a cinética de espermatozoides ovinos após descongelamento. In: SIMPÓSIO DE BIOQUÍMICA E BIOTECNOLOGIA, 3., 2013, Londrina. Anais... Londrina: Biochemistry and Biotechnology Reports, 2013. v. 2, p. 21-24.

CRUZ JÚNIOR, C. A. Caracterização anatômica e histological da cérviz de ovelhas da raça Santa Inês. 2006. Dissertação (Mestrado em Ciências Agrárias) Universidade de Brasília, Brasília.

DIDION, B. A. Computer-assisted semen analysis and its utility for profiling boar semen samples. Theriogenology, California, v. 70, n. 8, p. 1374-1376, 2008.

FOULKES, J. A. The separation of lipoproteins from egg yolk and their effect on the motility and integrity of bovine spermatozoa. Journal of Reproduction and Fertility, Oxford, v. 49, n. 2, p. 277-284, 1977.

GOULARTE, K. L. Influencia das proteinas do plasma seminal sobre a qualidade do semen ovino congelado. 2009. Dissertação (Mestrado em Medicina Veterinária) Universidade Federal de Pelotas, Pelotas.

GRAHAM, J. K.; FOOTE, R. H. Effect of several lipids fatty acyl chain length and degree of insaturation on the motility of bull spermatozoa after cold chock and freezing. Cryobiology, New York, v. 24, n. 1, p. 42-52, 1987.

HARRISON, R. A. P.; VICKERS, S. E. Use of fluorescent probes to assess membrane integrity in mammalian spermatozoa. Journal of Reproduction and Fertility, Oxford, v. 88, n. 1, p. 343-352, 1990.

HOLT, W. V. Basic aspects of frozen storage semen. Animal Reproduction Science, Amsterdam, v. 62, n. 1, p. 3-22, 2000a.

Fundamental aspects of sperm cryobiology: the importance of species and individual differences. Theriogenology, California, v. 53, n. 2, p. 47-58, $2000 \mathrm{~b}$.

HU, J. H.; LI, Q. W.; ZAN, L. S.; JIANG, Z. L.; JH, A.; WANG, L. Q.; YH, J. The cryoprotective effect of lowdensity lipoproteins in extenders on Bull spermatozoa following freezing-thawing. Animal Reproduction Science, Amsterdam, v. 117, n. 1-2, p. 11-17, 2010.

JEYENDRAN, R. S.; VAN DER VEM, H. H.; PEREZPELAEZ, M.; CRABO, B. G.; ZANEVELD, L. J. Development of an assay to assess the functional integrity of the human sperm membrane and its relationship to other semen characteristics. Journal of Reproduction and Fertility, Oxford, v. 47, n. 1, p. 219-228, 1984.
JIANG, Z.; LI, Q.; LI, W.; HU, J. H.; ZHAO, H. W.; ZHANG, S. S. Effect of low density lipoproteins on DNA integrity of freezing thawing boar sperm by neutral comet assay. Animal Reproduction Science, Amsterdam, v. 99, n. 3-4, p. 401-407, 2007.

LIMA, F. R. G. Pesquisa de novo método de congelação para sêmen de ovinos santa Inês. 2010. Tese (Doutorado integrado em Zootecnia) - Universidade Federal do Ceara, Fortaleza.

MAIA, M. S. Viabilidade espemática e geração de metabólitos reativos ao oxigênio (ROS) no semen ovino criopreservado em diluidor aditivado de lauril sulfato de sódio (OEP), Trolox-C e catalase. 2006. Tese (Doutorado em Medicina Veterinária) - Universidade Estadual Paulista, Botucatu.

MANJUNATH, P.; NAUC, V.; BERGERON, A.; MÉNARD, M. Major proteins of bovine seminal plasma bind to the low-density lipoprotein fraction of hen's egg yolk. Biology of Reproduction, Madison, v. 67, n. 4, p. 1250-1258, 2002.

MARCO-JIMÉNEZ, F.; PUCHADES, S.; MOCÉ, E.; VIUDES-DE-CARTRO, M. P.; VICENTE, J. S.; RODRIGUEZ, M. Use of powdered egg yolk vs fresh egg yolk for the cryopreservation of ovine semen. Reproduction in Domestic Animals, Linköping, v. 39, n. 6, p. 438-441, 2004.

MELO, M. I. V.; HENRY, M. Teste hiposmótico na avaliação do sêmen eqüino. Arquivo Brasileiro de Medicina Veterinária e Zootecnia, Belo Horizonte, v. 51, n. 6, p. 71-78, 1999.

MOUSSA, M.; MARTINET, V.; TRIMECHE, A.; TAINTURIER, D.; ANTON, M. Low density lipoproteins extracted from hen egg yolk by an easy method: cryoprotective effect on frozen-thawed bull semen. Theriogenology, California, v. 57, n. 6, p. 16951706, 2002.

MOUSTACAS, V. S.; ZAFFALON, F. G.; LAGARES, M. A.; LOAIZA-ECHEVERRI, A. M.; VARAGO, F. C.; NEVES, M. M.; HENEINE, L. G. D.; ARRUDA, R. P.; HENRY, M. Natural, but not lyophilized, low density lypoproteins were an acceptable alternative to egg yolk for cryopreservation of ram semen. Theriogenology, California, v. 75, n. 2, p. 300-307, 2011.

NEVES, M. M.; HENEINE, L. G. D.; HENRY, M. Cryoprotection effectiveness of low concentrations of natural and lyophilized LDL (low density lipoproteins) on canine spermatozoa. Arquivo Brasileiro de Medicina Veterinária e Zootecnia, Belo Horizonte, v. 66, n. 3, p. 769-777, 2014. 
PACE, M. M.; GRAHAM, E. F. Components of egg yolk which protect bovine spermatozoa during freezing. Journal of Animal Science, Champaign, v. 39, n. 6, p. 1144-1149, 1974.

RABASSA, V. R.; TABELEÃO, V. C; PFEIFER, L. F. M.; SCHNEIDER, A.; ZIGUER, E. A.; SCHOSSLER, E.; SEVERO, N. C.; DEL PINO, F. A. B.; CORRÊA, M. N. Efeito das técnicas transcervical e laparoscópica sobre a taxa de prenhez de ovelhas inseminadas em tempo-fixo. Ciência Animal Brasileira, Goiânia, v. 8, n. 1, p. 127133, 2007.

SALAMON, S.; MAXWELL, W. M. C. Storage of ram semen. Animal Reproduction Science, Amsterdam, v. 62, n. 1-3, p. 77-111, 2000.

SALAMON, S.; VISSER, D. Effect of composition of tris-based diluent 1 and of thawing solution on survival of ram spermatozoa frozen by the pellet method. Australian Journal of Biological Science, East Melbourne, v. 25, n. 3, p. 605-618, 1972.

SAMPAIO, I. B. M. Estatística aplicada à experimentação animal. Belo Horizonte: FEPMVZ/UFMG, 1998. 221 p.

SILVA, M. C.; MOURA, L. C. O.; VAZ DE MELO, M. I.; MAMBRINI, J. V. M.; NEVES, M. M.; HENRY, M. R. J. M.; SNOECK, P. P. N. Prolonged post cooling but not pre-cooling equilibriumlength improves the viability of ram sperm cryopreserved inan extender containing low-density lipoproteins. Small Ruminant Research, Arkansas, v. 119, n. 1, p. 88-95, 2014.
STRZEŻEK, R.; KOZIOROWSKA-GILUN, M.; STAWISZYŃSKA, M. Cryopreservation of canine semen: the effect of two extender variants on the quality and antioxidant properties of spermatozoa. Polish Journal of Veterinary Sciences, Olsztyn-Kortowo, v. 15, n. 4, p. 721-726, 2012.

TILBURG, M. F. V.; SILVA, J. F. S.; DIAS, A. J. B.; QUIRINO, C. R.; FAGUNDES, B. Influência da insulina no congelamento e resfriamento do sêmen ovino. Ciência Animal Brasileira, Goiânia, v. 9, n. 3, p. 731-739, 2008.

TONIETO, R. A. Uso de diferentes crioprotetores em diluentes para sêmen ovino congelado. 2008. Dissertação (Mestrado em Veterinária) - Programa de Pós-Graduação em Veterinária, Universidade Federal de Pelotas, Pelotas.

VARELA JÚNIOR, A. S.; CORCINI, C. D.; ULGUIM, R. R.; ALVARENGA, M. V.; BIANCHI, I.; CORRÊA, M. N.; LUCIA, T. J. R.; DESCHAMPS, J. C. Effect of low density lipoprotein on the quality of cryopreserved dog semen. Animal Reproduction Science, Amsterdam, v. 115, n. 1-4, p. 323-327, 2009.

VERA-MUNOZ, O.; AMIRAT-BRIAND, L.; DIAZ, T.; VÁSQUEZ, L.; SCHMIDT, E.; DESHERCES, S.; ANTON, M.; BENCHARIF, D.; TAINTURIER, D. Effect of semen dilution to low-sperm number per dose on motility and functionality of cryopreserved bovine spermatozoa using low-density lipoproteins (LDL) extender: Comperison to Tryladil ${ }^{\mathbb{}}$ and Bioxcell ${ }^{\circledR}$. Theriogenology, California, v. 71, n. 6, p. 895-900, 2009.

WATSON, P. F. The roles of lipid and protein in the protection of ram spermatozoa at $5^{\circ} \mathrm{C}$ by egg yolk lipoprotein. Journal of Reproduction and Fertility, Oxford, v. 62, n. 2, p. 483-492, 1981. 